\title{
Invited Discussion on: Combined Breast Reduction Augmentation
}

\author{
Kamran Khoobehi ${ }^{1}$
}

Received: 22 February 2019/Accepted: 2 March 2019/Published online: 15 March 2019

(C) Springer Science+Business Media, LLC, part of Springer Nature and International Society of Aesthetic Plastic Surgery 2019

Level of Evidence $V$ This journal requires that authors assign a level of evidence to each article. For a full description of these Evidence-Based Medicine ratings, please refer to the Table of Contents or the online Instructions to Authors www.springer.com/00266.

The challenge of achieving an aesthetically pleasing and lasting breast shape after breast reduction is obvious to all plastic surgeons. The goals of reduction are to reduce the size and at the same time enhance cleavage, upper pole fullness, nipple areola projection and decrease lateral fullness. The most common procedure for breast reduction is an inverted-T inferior pedicle [1-3]. The shortcoming of the inferiorly based reduction has been less than optimal in regards to breast projection and bottoming out [4]. There have been many different techniques to accomplish these goals mainly by changing the pedicle from inferior to superior or medial and autoaugmentation. Superior and medial pedicles have grown in favor with many surgeons to prevent bottoming out and provide more upper pole fullness [5]. Vertical mammoplasty with a superior pedicle blood supply is superiorly based with removal of parenchyma from the inferior pole of the breast to prevent bottoming out [6-9]. The limitation for this technique is breast reductions of $500 \mathrm{~g}$ or less [6].

Dr. Hammond published his technique of using a lower island flap transposition technique for control of the upper

Kamran Khoobehi

khoobehi@aol.com

1 Louisiana State University, 3901 Veterans Blvd, Metairie, USA pole in a circumvertical mastopexy. In an effort to optimize upper pole fullness, this technique combines the advantages of a circumvertical skin pattern with a lower island flap of skin and parenchyma which is transposed into the upper pole of the breast [10].

The other option is fat grafting at the time of the breast reduction and/or mastopexy. This utilizes the direct breast augmentation of the upper pole without implant use. The disadvantage of this procedure is loss of fat with weight loss [11]. The advantages of the autologous tissue for augmentation of the upper pole compared to the use of implants are numerous, including implant-related complications, dissociation of the breast tissue and implant and need for implant exchange down the road.

This paper presents an option that addresses the issues of breast reduction and/or mastopexy. The issue of upper pole fullness is addressed using micro-textured implants to add volume; and the issue of bottoming out is addressed by placing implants fully under the muscle to prevent stretching the lower pole. The results show patients with great projection, upper fullness and aesthetically pleasing results. The most impressive part of the paper is the results that show breast shapes that are hard to achieve with lift and/or reduction alone.

Some questions still remain on the long-term effects of complete submuscular implants, including their complication rates, need for revisions and effects on tissue if removed in the future. The weight of the overlying breast tissues, in most of the figures provided, shows breast reductions over $250 \mathrm{~g}$. The remaining breast tissue may still be at risk of causing a waterfall deformity, although it 
appears to be less or at a slower rate due to the decreased weight of the breast parenchyma. As mentioned in this paper, there are no reported cases of pseudoptosis, but the follow-up is short (average 2 years). There are implantrelated complications, such as possible capsular contracture, ALCL and possible nipple necrosis. There were 3 out of 366 patients who developed grade III or IV capsular contracture, which would not be an issue with autoaugmentation or fat grafting. Although this is a very low rate, it is still a unique risk associated with implant use. Recent research has suggested a reproducible association between textured implants and the development of breast implantassociated anaplastic large cell lymphoma (BIA-ALCL), a potentially fatal $\mathrm{T}$ cell lymphoma [12]. The literature does not differentiate micro-textured versus macrotextured implants; however, the use of the smooth implants may eliminate this risk. There were two cases of nipple necrosis, which was placed in the tissue-related complication category. It is uncertain from the paper what role an underlying implant may play on affecting the nipple-areolar complex blood supply. Overall, this paper describes alternatives to present to patients who have both large and ptotic breasts. The results are aesthetically pleasing especially with larger breasts with follow-up of 6 month to 4 years as shown in the figures provided. I commend the authors for sharing their methods and patient results.

\section{Compliance with Ethical Standards}

Conflict of interest The authors have no financial interest to declare in relation to the content of this discussion or of the associated article.

Ethical Approval This article does not contain any studies with human participants or animals performed by any of the authors.
Informed Consent Informed consent is not required for this type of article.

\section{References}

1. Wise RJ, Gannon JP, Hill JR (1963) Further experience with reduction mammoplasty. Plast Reconstr Surg 32:12-20

2. Wise RJ (1956) A preliminary report on a method of planning the mammaplasty. Plast Reconstr Surg 17:367-375

3. Courtiss EH, Goldwyn RM (1977) Reduction mammaplasty by the inferior pedicle technique: an alternative to free nipple and areola grafting for severe macromastia or extreme ptosis. Plast Reconstr Surg 59:500-507

4. Hammond DC, Loffredo MA (2012) Breast reduction. Plast Reconstr Surg 129(5):829e-839e

5. Hall-Findlay EJ, Shestak KC (2015) Breast reduction. Plast Reconstr Surg 136(4):531e-544e

6. Lassus C (1970) A technique for breast reduction. Int Surg 53:69-72

7. Lassus C (1987) Breast reduction: evolution of a technique. A single vertical scar. Aesthet Plast Surg 11:107-112

8. Lassus C (1996) A 30-year experience with vertical mammaplasty. Plast Reconstr Surg 97:373-380

9. Lejour M (1994) Vertical mammaplasty and liposuction of the breast. Plast Reconstr Surg 94:100-114

10. Hammond DC, O'Connor EA (2014) The lower island flap transposition (LIFT) technique for control of the upper pole in circumvertical mastopexy. Plast Reconstr Surg 134(4):655-660

11. Khoobehi K, Sadeghi A (2009) Single staged mastopexy with autologous fat grafting. Plast Reconstr Surg 124(4S):8-9

12. Tandon VJ, DeLong MR, Ballard TN, Clemens MW, Brandt KE, Kenkel JM, Cederna PS (2018) Evolving trends in textured implant use for cosmetic augmentation in the United States. Plast Reconstr Surg 142(6):1456-1461

Publisher's Note Springer Nature remains neutral with regard to jurisdictional claims in published maps and institutional affiliations. 